\title{
RESPONSE OF ENGLISH OAK (QUERCUS ROBUR L.) TREES TO BIOSTIMULANTS APPLICATION IN THE URBAN ENVIRONMENT
}

\author{
by F. Ferrini' ${ }^{1}$ and F.P. Nicese ${ }^{2}$
}

\begin{abstract}
The influence of two biostimulants on leaf gas exchanges and leaf characteristics of English oak (Quercus robur L.) was evaluated in a urban environment over two growing seasons. Trunk diameter and shoot growth were also monitored. Treatments included 1) control (no biostimulants); 2) Root Grow WPTM, a commercial hydrosoluble powder made of a mix of humic acids, marine algae, Yucca extracts, vitamins, amino acids, and nitrogen-fixing bacteria; and 3) Mycobacter DPTM, a commercial granular mix of endo- and ectomycorrhizal fungi, biostimulants bacteria, humic acids, carbohydrates, vitamins, acrylamide, Yucca extracts, and marine algae. No statistical differences were found on trunk diameter increase and shoot growth. Photosynthesis, evaporation rate, and water-use efficiency were higher in plants treated with biostimulants than control plants on every observation date. No differences were found regarding leaf fresh/dry weight ratio and specific leaf weight, while chlorophyll content, leaf area, and leaf dry weight were higher in the treated plants, especially in the second year after planting. Nitrogen concentration in leaf tissue was higher in the treated trees, while the content of the other mineral nutrients was not affected by the products. No differences emerged between the two biostimulants used. Though this study supports the utility of biostimulants application as an aid to promote plant establishment in adverse sites, especially in terms of plant physiology, it is difficult to make specific recommendations on their application and on the choice of the best biostimulant product for Quercus robur in our conditions.
\end{abstract}

Key Words. Biostimulants; photosynthesis; growth; urban environment; physiology.

Urban trees are subjected to several post-transplant stresses. Root loss, water deficit, insects and diseases, and adverse chemical and physical soil characteristics are considered chronic and widespread stresses in urban sites. Thus, as pointed out by other authors (Kelting 1997), it is essential to minimize stress for trees by providing the best growing conditions possible, so to increase post-transplant survival and encourage rapid establishment. Among the methods that can be used for this purpose, organic biostimulants have been strongly marketed as products able to increase plant growth. They are defined as "nonnutritional products that may reduce fertilizer use and increase yield and resistance to water and temperature stresses and positively affect plant growth and physiology" (Russo and Berlyn 1990). Biostimulants are, in general, made of a mix of humic acids, marine algae extracts, mycorrhizal fungi, vitamins, and other compounds-which can vary according to the producer.

Russo and Berlyn (1990) stated that organic biostimulants improve root and shoot growth, increase resistance to stresses (both biotic and abiotic), and reduce the need for high levels of nitrogen fertilization through increased efficiency of nutrients and water uptake. However, some controversial results do exist, especially regarding their effects on root growth (Laiche 1991; Kelting et al. 1997; Kelting et al. 1998a; Kelting et al. 1998b).

Some components, such as marine algae, can increase plant growth and stress resistance (Russo and Berlyn 1992; Berlyn and Sivaramakrishnan 1996). Crouch et al. (1992) stated that these effects can be due to the auxin and cytokinin compounds present in seaweed extracts. According to the theory of other authors, internal production of cytokinin may be limited during periods of plant stress. Biostimulants, because of their cytokinin content, may be beneficial to overcome plant stress (Csinzinszky 1990). The addition of vitamins such as ascorbic acid into the mix also stimulates growth and chlorophyll synthesis (Russo and Berlyn 1992).

The inoculation of ectomycorrhizae has been shown to stimulate tree growth and delay yellowing of leaves in autumn (Garbaye and Churin 1996). On this subject, Kuhns (1980) stated that plants with mycorrhizal roots may survive and grow better than nonmycorrhizal plants in disturbed soils such as those frequently present in the urban sites. The mechanism through which this is accomplished is not well understood, though it is probably related to an ability of the fungus hyphae to selectively absorb water and essential 
mineral elements under adverse conditions. However, in a recent work, the application of mycorrhizal-forming fungi to the backfill soil at planting had no impact on live oak the first 30 months after planting (Gilman 2001). The symbiotic mycorrhizal association also produces plant growth regulators affecting plant development and represents a physical barrier against soilborne pathogens (Kuhns 1980; Garbaye and Churin 1996).

The problem is that most of the fungi are speciesspecific; therefore, a fungus may benefit one host more than another. Only a few research reports are available regarding the effects of biostimulants on post-transplant growth and physiology of balled-and-burlapped trees (Kelting et al. 1998a). Therefore, the aim of this research was to evaluate the effects of two commercial biostimulants on the growth and leaf physiology and characteristics of English oak (Quercus robur L.) transplanted in an adverse urban site.

\section{MATERIALS AND METHODS Plant Material}

Thirty-six uniform, English oak (Quercus robur L. 'Fastigiata') trees grafted onto seedlings, 8 to $8.5 \mathrm{~m} \mathrm{(27}$ to $28 \mathrm{ft}$ ) tall, $25 \mathrm{~cm}$ (10 in.) circumference, balled and burlapped $[\mathrm{B} \& \mathrm{~B}$; root ball diameter was $90 \mathrm{~cm}(3 \mathrm{ft})$ according to international standard] were planted in March 1999, before budbreak, in the main avenue of the new campus of the University of Florence, Italy. Until the mid-1990s, the area was used as a rubble dump of the new university settlement; in fall 1998, the rubble was removed and the clayey native soil was covered with a layer of about 80 to $100 \mathrm{~cm}$ (about $3 \mathrm{ft}$ ) of clayey soil from a local source. Planting holes were two times the width and the same depth of the root ball (approximately $60 \mathrm{~cm}$ ). Trees were placed in the planting holes backfilled with excavated soil amended with 80 L (20 gal.; $6 \%$ in volume) of peat moss; some soil was added to compensate for settling. After planting, trees were watered during the dry periods twice a week (100 to $120 \mathrm{~L}$ of water/tree/week).

\section{Experimental Design}

The experimental design consisted of 36 trees randomly distributed into 12 replicates of the three following treatments applied at planting: 1) control (no biostimulants), 2) Biotech ${ }^{\circledR}$ Root Grow WPTM, and 3) Biotech ${ }^{\circledR}$ Mycobacter DPTM

Root Grow WP is a hydrosoluble powder made of a mix of humic acids, marine algae, Yucca extracts, vitamins, amino acids, and nitrogen-fixing bacteria; Mycobacter DP is a mix of endo- and ectomycorrhizal fungi, biostimulants bacteria, humic acids, carbohydrates, vitamins, acrylamide, Yucca extracts, and marine algae. Trees were planted $10 \mathrm{~m}$ apart in the wide footpaths on one side of the main avenue in a completely randomized design.

\section{Treatment Application}

The biostimulants were applied at planting in the following way: $5 \mathrm{~g}$ of Root Grow WPTM powder were diluted into $5 \mathrm{~L}$ of water and poured at the edge of the root ball; treatment with Mycobacter DPTM was made by drilling five holes around the root ball and filling each hole with $25 \mathrm{~g}$ of products. Biostimulants were then applied monthly from the end of March to the end of July (Root Grow WP, total of $25 \mathrm{~g} /$ plant/year) and bimonthly (Mycobacter DP, $375 \mathrm{~g} /$ plant/year) according to the producer's recommendations. No fertilizers were applied during the experimental period.

\section{Data Collection}

Trunk diameter was measured at $120 \mathrm{~cm}$ from the ground, at planting and the two following winters. Shoot growth was measured on 25 shoots per plant at the end of the growing seasons. Leaf area was calculated from 50 leaves per plant measured with a leaf area meter (CID CI-203, CID Inc., Vancouver, WA, U.S.) 135 days after budbreak. Leaf fresh and dry weight and dry/fresh weight ratio were also determined.

Specific leaf weight (SLW) was calculated as leaf dry weight divided by leaf area.

Instantaneous net photosynthesis (Pn), evaporation rate $(\mathrm{E})$, and water-use efficiency (WUE, calculated dividing Pn by E) were measured 75, 90, 120 and 135 days after budbreak (ABB), using the CIRAS-1 portable infrared gas analyzer (PP Systems, Hertfordshire, U.K.).The readings were taken between 800 and 1800 hours on eight fully expanded leaves (chosen in the outer part of the crown and at different heights) per plant under conditions of light saturation (PAR $>1000$ umol $\left.* \mathrm{~m}^{-2} * \mathrm{~s}^{-1}\right)$.

Chlorophyll content was determined 90 and 135 days $\mathrm{ABB}$ on the same leaves with a portable chlorophyll meter (SPAD-502 Minolta Corp., Ramsey, N.J., U.S.) previous calibration curve done by measuring the absorbance at 664, 647 and $625 \mathrm{~nm}$, with an Hitachi U-2000 spectrophotometer, after extraction with dimethylformamide $(\mathrm{DMF})\left(\mathrm{R}^{2}=93.3 \%\right.$, regr. eq. $-9.84+0.713 x$ ) (Moran 1982). 
Nutrient analyses were performed at the end of the second growing season by the Demetra S.n.c. Laboratory for Plant Tissue Analyses in Pescia, Italy.

\section{Data Analysis}

All the data were subjected to one-way analysis of variance using SPSS Statistical Package (Release 8.0) with Bliss transformation for percent data. Treatment means were separated by LSD, with $p \leq 0.05$ level of significance.

\section{RESULTS AND DISCUSSION}

No significant differences were found between the biostimulant-treated trees and the control ones, regarding trunk diameter and shoot growth (Table 1), thus confirming findings by other authors who did not find appreciable increase in plant growth from biostimulant applications, either applied on container-grown plants or after transplanting (Laiche 1991, Kelting et al. 1997, 1998a).

In year 2 (2000), the biostimulant treatments positively affected leaf area and, to a limited extent, leaf dry

Table 1. Influence of the biostimulants on trunk diameter and shoot growth of Quercus robur 'Fastigiata' trees.

\begin{tabular}{lllll}
\hline Treatment & $\begin{array}{l}\text { Diameter }(\mathrm{cm}) \\
1999\end{array}$ & $\begin{array}{l}\text { Diameter }(\mathrm{cm}) \\
2000\end{array}$ & $\begin{array}{l}\text { Shoot growth }(\mathrm{cm}) \\
1999\end{array}$ & $\begin{array}{l}\text { Shoot growth }(\mathrm{cm}) \\
2000\end{array}$ \\
\hline Mycobacter & 9.295 & 9.90 & 8.32 & 9.59 \\
Root Grow & 8.783 & 9.76 & 7.99 & 8.89 \\
Control & 9.110 & 9.32 & 6.54 & 7.93 \\
$p$-value & 0.269 & 0.265 & 0.089 & 0.112 \\
\hline
\end{tabular}

weight, while no differences were detected regarding SLW and dry/fresh weight ratio (Table 2). Plant response to treatments in terms of leaf area was similar in both years of observation.

Table 3 shows that leaf gas exchanges (cumulative data of four sampling dates in both years) were higher in trees treated with the biostimulants in both years.
Water-use efficiency (WUE), calculated by dividing Pn by evaporation (E) rate measurements, showed that the treated trees also used water more efficiently than control ones, especially in the first year after planting. Therefore, based on gas exchange and water-use efficiency, treated English oak used water more efficiently while maintaining photosynthesis better than the controls. The role of the biostimulants is probably indirect and comes from their supposed influence on stimulating drought tolerance (Russo and Berlyn 1990). This can be of some advantage to the plants because it can contribute to the maintenance of a sufficient level of leaf gas exchange, which can be severely lowered in case of drought. Water deficit can also damage the photosynthetic apparatus because it dehydrates tissues, which after that respond more slowly to changes in environmental water status (Cormich 2000).

The chlorophyll content of the leaves, as shown in Table 4, was positively influenced by the treatments in both years, consistent with the treatment effects on leaf gas exchanges.

Leaf mineral analyses indicated that biostimulants increased $\mathrm{N}$ content, while no differences were found in the other mineral nutrients (Table. 5). These results were consistent with Garbaye and Churin (1996), who found a higher leaf nitrogen concentration in Tilia tomentosa trees inoculated with a mixed inoculum of mycorrhizal fungi, while the application of the single fungus species did not show any appreciable influence. The possible nutrient effect by the applied biostimulants is probably related to their content in humic acids, which positively affect water retention and act as a nutrient reserve because of their high exchange

Table 2. Influence of the biostimulants on leaf dry weight, dry/fresh weight, leaf area, SLW (specific leaf weight, leaf dry weight/leaf area) of Quercus robur 'Fastigiata' trees in 1999 and 2000. Sampling date: 135 days after budbreak.

\begin{tabular}{|c|c|c|c|c|c|c|c|c|}
\hline \multirow[b]{2}{*}{ Treatment } & \multicolumn{4}{|c|}{1999} & \multicolumn{4}{|c|}{2000} \\
\hline & $\begin{array}{l}\text { Dry } \\
\text { weight }(\mathrm{g})\end{array}$ & $\begin{array}{l}\text { Dry/fresh } \\
\text { weight } \\
\text { ratio }\end{array}$ & $\begin{array}{l}\text { SLW } \\
\left(\mathrm{mg} / \mathrm{cm}^{2}\right)\end{array}$ & $\begin{array}{l}\text { Leaf } \\
\text { area }\left(\mathrm{cm}^{2}\right)\end{array}$ & $\begin{array}{l}\text { Dry } \\
\text { weight }(\mathrm{g})\end{array}$ & $\begin{array}{l}\text { Dry/fresh } \\
\text { weight } \\
\text { ratio }\end{array}$ & $\begin{array}{l}\text { SLW } \\
\left(\mathrm{mg} / \mathrm{cm}^{2}\right)\end{array}$ & $\begin{array}{l}\text { Leaf } \\
\text { area }\left(\mathrm{cm}^{2}\right)\end{array}$ \\
\hline Mycobacter & 138 & 0.464 & 6.69 & $20.62 \mathrm{ab}^{*}$ & $203 \mathrm{a}$ & 0.456 & 5.30 & $38.31 \mathrm{a}$ \\
\hline Root Grow & 130 & 0.478 & 6.04 & $21.51 \mathrm{a}$ & $201 \mathrm{a}$ & 0.455 & 5.03 & $39.96 \mathrm{a}$ \\
\hline Control & 130 & 0.496 & 7.14 & $18.22 \mathrm{~b}$ & $157 \mathrm{~b}$ & 0.461 & 4.89 & $32.09 \mathrm{~b}$ \\
\hline$p$-value & 0.860 & 0.481 & 0.228 & 0.015 & 0.042 & 0.784 & 0.58 & 0.000 \\
\hline
\end{tabular}

${ }^{*}$ Means with different letters are significantly different at $p \leq 0.05$. 
Table 3. Influence of the biostimulants on net photosynthesis (Pn) $\left(\mu \mathrm{mol} \mathrm{CO} * \mathrm{~m}^{-2} * \mathrm{~s}^{-1}\right)$, evaporation rate $(\mathrm{E})\left(\mathrm{mmol} \mathrm{H}_{2} \mathrm{O}\right.$ $* \mathrm{~m}^{-2} * \mathrm{~s}^{-1}$ ), WUE (water-use efficiency: Pn/E) of Quercus robur 'Fastigiata' trees. Average of four sampling dates in 1999 and 2000.

\begin{tabular}{|c|c|c|c|c|c|c|}
\hline \multirow[b]{2}{*}{ Treatment } & \multicolumn{3}{|c|}{1999} & \multicolumn{3}{|c|}{2000} \\
\hline & Pn & $\mathrm{E}$ & WUE & Pn & $\mathrm{E}$ & WUE \\
\hline Mycobacter & $12.31 \mathrm{a}^{*}$ & $2.15 \mathrm{a}$ & $5.73 \mathrm{a}$ & $12.44 \mathrm{a}$ & 2.67 & $4.66 \mathrm{ab}$ \\
\hline Root Grow & $12.06 \mathrm{a}$ & $2.13 \mathrm{a}$ & $5.66 \mathrm{a}$ & $13.54 \mathrm{a}$ & 2.71 & $5.00 \mathrm{a}$ \\
\hline Control & $9.06 \mathrm{~b}$ & $1.83 \mathrm{~b}$ & $4.94 \mathrm{~b}$ & $11.09 \mathrm{~b}$ & 2.57 & $4.32 \mathrm{~b}$ \\
\hline$p$-value & 0.000 & 0.004 & 0.002 & 0.014 & 0.795 & 0.041 \\
\hline
\end{tabular}

*Means with different letters are significantly different at $p \leq 0.05$.

Table 4. Chlorophyll content $\left(\mu \mathrm{g} * \mathrm{~g}^{-1}\right)$ of Quercus robur 'Fastigiata' leaves 90 and 135 day after budbreak (ABB) as affected by commercial biostimulants.

\begin{tabular}{llllll}
\hline & \multicolumn{2}{c}{1999} & & 2000 \\
\cline { 2 - 3 } \cline { 5 - 6 } & Chlorophyll & Chlorophyll & & Chlorophyll & Chlorophyll \\
& $90 \mathrm{ABB}$ & $135 \mathrm{ABB}$ & & $90 \mathrm{ABB}$ & $135 \mathrm{ABB}$ \\
\hline Mycobacter & $13.85 \mathrm{a}^{*}$ & 17.71 & & $14.99 \mathrm{a}$ & 16.09 \\
Root Grow & $13.83 \mathrm{a}$ & 17.73 & & $14.25 \mathrm{a}$ & 16.57 \\
Control & $12.66 \mathrm{~b}$ & 16.45 & & $12.90 \mathrm{~b}$ & 15.25 \\
$p$-value & 0.000 & 0.097 & & 0.000 & 0.150 \\
\hline${ }^{*}$ Means with & different letters are & 0.09 &
\end{tabular}

${ }^{*}$ Means with different letters are significantly different at $p \leq 0.05$ (year 2)

suppressed due to poor soil conditions and where little water is available, according to Smiley et al. (1997). These products seem to be more effective in pedoclimatic conditions than in the controlled environment of the nursery or where the plants are well treated after transplanting. However, since their effects were primarily on leaf gas exchange and leaf characteristics, further research is needed to fully demonstrate their advantages both in terms of plant growth and in economic terms. In fact, the cost versus benefits analysis has shown a high ratio for Root Grow WP (US\$1.2/tree/ year), while Mycobacter DP seemed to be too expensive for a large-scale treatment (US\$7.15/ tree/year).

Moreover, it has to be pointed out that, consistent with what was found in a study carried out on container-grown plants of Acer platanoides and Liquidambar styraciflua (Nicese and Ferrini, unpublished data), no differences emerged between the two products used. English oak generally forms ectomycorrhizae, and we expected that Mycobacter DP, made of

capacity and capability to form water-soluble complexes with metal ions, thus possibly enhancing the adsorption of some mineral nutrients by roots (Kelting 1997). A positive effect of products containing humic acids on nitrogen uptake has been shown by other authors (Tattini et al. 1991), who stated that they are especially positive at low concentration, while a negative effect can be observed at high rates of application. The same authors also stated that humic concentrations stimulated root development that probably represents the most important effect of humic acids on plant growth, even if some contrasting experience are reported in the literature (Kelting et al. 1998a). As a matter of fact, the higher chlorophyll content, leaf area, and leaf gas exchange found in our research resulted in a less than expected enhancement in shoot growth and stem diameter. We hypothesize that in the first two years after transplanting, the biomass partitioning is more to increase root growth than top growth, though, in the long term, once a vigorous growth resumes, it may also result in a greater top growth.

The results of this research support the utility of biostimulants application as a potential alternative to fertilizers to stimulate fine root and ectomycorrhizae development, above all where natural mycorrhizae are a mix of these fungi, could be more effective. Thus, is difficult to make specific recommendations on the choice of the best biostimulant product for Quercus robur in terms of growth response to the treatment in our conditions.

Table 5. Leaf mineral content as affected by commercial biostimulants.

\begin{tabular}{llllll}
\hline Treatment & $\mathrm{N} \%$ & $\mathrm{P} \%$ & $\mathrm{~K} \%$ & $\mathrm{Mg} \%$ & $\mathrm{Fe} \mathrm{ppm}$ \\
\hline Mycobacter & $2.35 \mathrm{a}^{*}$ & 0.137 & 0.86 & 0.317 & 256.3 \\
Root Grow & $2.25 \mathrm{a}$ & 0.137 & 0.92 & 0.267 & 223.3 \\
Control & $2.04 \mathrm{~b}$ & 0.130 & 0.82 & 0.287 & 212.7 \\
$p$-value & 0.038 & 0.216 & 0.452 & 0.096 & 0.499
\end{tabular}

${ }^{*}$ Means with different letters are significantly different at $p \leq 0.05$.

\section{LITERATURE CITED}

Berlyn, G.P., and S. Sivaramakrishnan. 1996. The use of organic biostimulants to reduce fertilizer use, increase stress resistance, and promote growth. Nat. Proc. Forest and Conservation Nursery Assoc., Salem, CT.

Cormich, G. 2000. Drought stress inhibits photosynthesis by decreasing stomatal aperture not by affecting ATP synthesis. Trends Plant Sci. 5(5):187-188.

Crouch, I. J., M.T. Smith, J. Van Staden, M.J. Lewis, and G.V. Hood. 1992. Identification of auxin in a commercial seaweed concentrate. J. Plant Physiol. 139:590-594. 
Csinzinszky, A.A. 1990. Response of two bell pepper (Capsicum annum L.) cultivars to foliar and soil-applied biostimulants. Soil Crop Sci. Soc. Fla. Proc. 49:199-203.

Garbaye, J., and J.L. Churin. 1996. Effect of ectomycorrhizal inoculation at planting on growth and foliage quality of Tilia tomentosa. J.Arboric. 22(1):29-33.

Gilman, E.F. 2001. Effect of nursery production method, irrigation and inoculation with mycorrhizal-forming fungi on establishment of Quercus virginiana. J. Arboric. 27(1): 30-39

Kelting, M. 1997. Effect of soil amendments and biostimulants on the post-transplant growth of landscape trees. M.S. thesis. Faculty of the Virginia Polytechnic Institute and State University, Blacksburg,VA.

Kelting, M., J. R. Harris, J. Fanelli, B. Appleton, and A. Niemiera. 1997. Humate-based biostimulants do not consistently increase growth of container-grown Turkish hazelnut. J. Environ. Hortoc. 15(4):197-199.

Kelting, M., J.R. Harris, J. Fanelli, and B. Appleton. 1998a. Humatebased biostimulants affect early post-transplant root growth and sapflow of balled and burlapped red maple. HortScience 33(2):342-344.

Kelting, M., J.R. Harris, J. Fanelli, and B. Appleton. 1998b. Biostimulants and soil amendments affect two-year posttransplant growth of red maple and Washington hawthorn. HortScience 33(5):819-822.

Kuhns, L.J. 1980. Potential benefits of mycorrhizae in the urban environment. Metro Tree Improvement Alliance (METRIA) Proc. 3:77-82.

Laiche, A,J., Jr. 1991. Evaluation of humic acids and slow-release fertilizers on container-grown landscape plants. Res. Rep. Mississippi Agric. and For. Exp. Sta. 16(7):1-3.

Moran, R. 1982. Formulae for determination of chlorophyllous pigments extracted with N,N-dimethylformamide. Plant Physiol. 69:1376-1381.

Russo, R.O., and G.P., Berlyn 1990. The use of organic biostimulants to help low-input sustainable agriculture. J. Sustain. Agric. 1(2):19-42.

Russo, R.O., and G.P. Berlyn 1992. Vitamin-humic-algal root biostimulant increases yield of green bean. HortScience 27:847.

Smiley, E.T., D.H. Marx, and B.R. Fraedrich. 1997. Ectomycorrhizal fungus inoculations of established residential trees. J. Arboric. 23(3):113-115.

Tattini, M., P. Bertoni, A. Landi, and M.L. Traversi. 1991. Effect of humic acids on growth and biomass partitioning of containergrown olive plants. Acta Hortic. 294:75-80.

\footnotetext{
1*Dipartimento di Produzione Vegetale

University of Milan

Via Celoria, 2 - 20133

Milan, Italy

francesco.ferrini@unimi.it
}

\author{
${ }^{2}$ Dipartimento di Ortoflorofrutticoltura \\ Università di Firenze \\ Viale delle Idee, 30 - 50019 \\ Sesto Fiorentino, Florence, Italy \\ ${ }^{*}$ Corresponding author
}

Résumé. L'influence de deux bio-stimulants sur les échanges gazeux des feuilles et les caractéristiques foliaires de chênes pédonculés (Qurecus robur L.) a été évaluée dans un environnement urbain durant deux saisons de croissance. Le diamètre du tronc et la croissance de la pousse ont aussi été suivis. Les divers traitements étaient les suivants: 1) groupe contrôle (aucun biostimulant), 2) Root Grow WPTM, une poudre commerciale hydrosoluble faite d'un mélange d'acides humiques, d'algues marines, d'extraits de Yucca, de vitamines, d'acides aminés et de bactéries fixatrices d'azote, 3) Mycobacter DPTM, un mélange granulaire commercial d'endo et d'ectomycorhizes, de bactéries bio-stimulantes, d'acides humiques, d'hydrates de carbone, de vitamines, d'acrylamide, d'extraits de Yucca et d'algues marines. Aucune différence statistique n'a été découverte dans la croissance en diamètre du tronc et celle de la pousse. La photosynthèse, le taux d'évaporation et l'utilisation efficace de l'eau ont été plus élevés aux différentes périodes chez les végétaux traités avec des bio-stimulants que ceux non traités. Aucune différence n'a été découverte en regard du ratio masse foliaire humide versus sèche ainsi que de la masse foliaire spécifique; cependant que le contenu en chlorophylle, la surface foliaire et la masse foliaire sèche étaient plus élevés chez les végétaux traités, particulièrement la seconde année après leur plantation. La concentration en azote dans le tissu foliaire était plus élevée chez les arbres traités, alors que ces substances n'affectaient pas le contenu en regard des autres éléments nutritifs. Aucune différence n'a émergé entre les deux biostimulants utilisés. Même si cette étude supporte l'idée d'employer des bio-stimulants comme une aide pour promouvoir la reprise des végétaux dans les sites difficiles, particulièrement en terme de physiologie végétale, il est difficile de faire des recommandations spécifiques quant à leur application et sur le choix du meilleur produit bio-stimulant pour le Quercus robur dans nos conditions.

Zusammenfassung. Über zwei Wachstumsperioden wurde der Einfluß von zwei Biostimulantien auf den Gasaustausch der Blätter und deren Charakteristika in einem städtischen Umfeld bewertet. Der Stammdurchmesser und die Wachstumsrate der Triebe wurden auch überwacht. Die Behandlungen schlossen 1. die Kontrolle (keine Stimulantien), 2.Wurzelwachstum WPIM, ein kommerzielles wasserlösliches Pulver aus Huminsäuren, Meeresalgen, YuccaExtracten, Vitaminen, Aminosäuren und Stickstoff-bindenden Bakterien und 3. Mycobacter DPIM, ein kommerzielles Granulat aus Endo- und Ektomycorrhizen, Biostimulants-Bakterien, Huminsäuren, Kohlenhydraten, Vitaminen, Acrylamiden. YuccaExtrakten und Meeresalgen. Am Stammdurchmesser und dem Triebwachstum wurden keine signifikanten Unterschiede 
gemessen. Photosynthese, Evaporationsrate und Wasserverbraucheffizienz waren bei Bäume mit Biostimulantien bei jeder Untersuchung größer als bei der unbehandelten Kontrollgruppe. Es gab keine Unterschiede bei dem Blattfrisch- und trockengewicht, während Chlorophyllanteil, Blattfläche und Blatttrockengewicht bei den gepflanzten Bäumen größer waren, besonders im zweiten Jahr nach der Pflanzung. Die Stickstoffkonzentration im Blattgewebe war in den behandelten Bäumen höher, währen die Produkte nicht den Anteil der anderen mineralischen Komponenten beeinflussten. Obwohl diese Studie die Verwendung von Biostimulantien als Hilfsmittel für die Etablierung von Bäumen auf schwierigen Standorten unterstützt, ist es schwierig, besondere Empfehlungen oder eine Auswahl des besten Produkts für Quercus robur in unserem Klima auszusprechen.

Resumen. Se evaluó la influencia de dos bioestimulantes sobre el intercambio de gas en la hoja y las características de la hoja del encino inglés (Quercus robur L.) en un ambiente urbano en dos estaciones de crecimiento. El diámetro del tronco y el crecimiento de los brotes también fue monitoreado. Los tratamientos fueron: 1) control (sin bioestimulantes); 2) Root Grow WPTM, un polvo comercial hidrosoluble hecho de una mezcla de ácidos húmicos, algas marinas, extractos de Yucca, vitaminas, aminoácidos y bacterias fijadoras de nitrógeno; y 3) Mycobacter DPTM, un granulado comercial compuesto de una mezcla de hongos endo y ectomicorrízicos, bacterias bioestimulantes, ácidos húmicos, carbohidratos, vitaminas, acrilamida, extractos de Yuca y algas marinas. No se encontraron diferencias estadísticas en el incremento del diámetro del tronco y el crecimiento de los brotes. La fotosíntesis, tasa de evaporación y eficiencia de uso del agua fueron mayores en las plantas tratadas con bioestimulantes que en las plantas de control, en los datos de cada observación. No se encontraron diferencias en la relación peso fresco/seco de la hoja y peso específico de la hoja, mientras que el contenido de clorofila, área foliar y peso seco de la hoja fueron más altos en las plantas tratadas, especialmente en segundo año después de la plantación. La concentración de nitrógeno en el tejido foliar fue más alta en los árboles tratados, mientras que los productos no afectaron el contenido de los otros nutrientes minerales. No emergieron diferencias entre los dos bioestimulantes usados. Por consiguiente, este estudio soporta la utilidad de las aplicaciones de bioestimulantes como una ayuda para promover el establecimiento de la planta en sitios adversos, especialmente en términos de la fisiología de la planta, por lo que es dificil hacer recomendaciones específicas sobre la escogencia de uno u otro producto para Quercus robur en nuestras condiciones. 